\title{
Generating $\mathrm{H}_{2}$ from a $\mathrm{H}_{2} \mathrm{O}$ molecule by catalysis using a small
}

\author{
$\mathrm{Al}_{6} \mathrm{Cu}$ cluster \\ Kang-Ning Li, Chuan-Lu Yang*, Yan-Xiao Han, Mei-Shan Wang, Xiao-Guang Ma, \\ Li-Zhi Wang \\ School of Physics and Optoelectronics Engineering, Ludong University, Yantai 264025, the \\ People's Republic of China
}

\begin{abstract}
Only one $\mathrm{H}$ atom is extracted from a single $\mathrm{H}_{2} \mathrm{O}$ molecule in a usual reaction for hydrogen generation. In this study, a three-step reaction has been identified for completely extracting $\mathrm{H}_{2}$ from $\mathrm{H}_{2} \mathrm{O}$ molecule with the catalysis of a small $\mathrm{Al}_{6} \mathrm{Cu}$ cluster, based on the first principles calculations. All the reactants, products, and transition states are determined by optimization calculation and confirmed by frequency analysis. The intrinsic reaction coordinate is also calculated to validate the reaction process. Results show that the whole reaction is an endothermic reaction. The charge distribution is used to understand the novel reaction. It is found that $\mathrm{Al}_{6} \mathrm{Cu}$ cluster can strongly capture $\mathrm{H}_{2} \mathrm{O}$ molecule and extract the $\mathrm{H}_{2}$ molecule completely, which may present a more efficient way to generate $\mathrm{H}_{2}$ from a single $\mathrm{H}_{2} \mathrm{O}$ molecule.
\end{abstract}

Keywords: $\mathrm{H}_{2}$ generation, $\mathrm{H}_{2} \mathrm{O}$ molecule, $\mathrm{Al}_{6} \mathrm{Si}$ cluster, catalysis

\section{Introduction}

To build a renewable energy system is one of the most critical issues for the sustainable development of the mankind society and the natural environment. The practical new energy source requires a renewable fuel to replace the traditional energy carrier.

*Corresponding author. Tel: +86 535 6672870. E-mail address: ycl@ldu.edu.cn. (C.L. Yang). 
Hydrogen is definitely an ideal fuel for this goal. Therefore, effective methods of hydrogen generation and storage have attracted considerable attention [1-3]. Hydrogen is considered as a clean alternative energy carrier because of its efficiency, abundance, and environmental friendliness [4]. Hydrogen also causes no pollution and produces almost threefold the gravimetric heat of combustion of gasoline [5-9]. Hydrogen generation has been extensively investigated by the reaction of aluminum-based system with water [10-28]. Russo et al. [13] studied the dynamics associated with the dissociation of water on an aluminum nanocluster using the ReaxFF reactive force field. Gai et al. [15] investigated hydrogen generation by the reaction of pure aluminum powder in water with the addition of $\mathrm{Al}(\mathrm{OH})_{3}, \gamma-\mathrm{Al}_{2} \mathrm{O}_{3}, \alpha-\mathrm{Al}_{2} \mathrm{O}_{3}$, or $\mathrm{TiO}_{2}$ at mild temperatures. Wang et al. [16] investigated the production of hydrogen from aluminum and its alloy powder with aqueous alkaline solutions. Uehara et al. [17] found that hydrogen gas can be generated in the wet cutting of aluminum and its alloys during a chemical reaction between the fresh surface of aluminum and water. Fan et al. [23] presented an effective method for producing hydrogen via the hydrolysis of milled Al-Bi-hydride (or salts) in pure water at room temperature. Zhao et al. [26] have reported that the hydrogen can be generated by splitting water with Al-Ca alloy. Chai et al. [27] investigated hydrogen generation using the reaction between aluminum and water. They explored the effect of $\mathrm{CoCl}_{2}$ and $\mathrm{NiCl}_{2}$ on aluminum water reaction, and found that the formation of the amorphous Co catalyst with high specific surface area plays an important role in the aluminum water reaction. An experiment conducted by Liu et al. also shows that the hydrolysis of aluminum powder can be efficiently improved by milling with hydrides. [28]. Therefore, aluminum may be the most promising candidate for hydrogen 
production.

The microscopic mechanism of the reaction between aluminum cluster and $\mathrm{H}_{2} \mathrm{O}$ molecule has been explored in some theoretical studies [29-33]. The intrinsic reaction coordinate (IRC) is obtained for $\mathrm{H}_{2} \mathrm{O}$ molecules, which dissociate into $\mathrm{H}_{2}$ on aluminum clusters. For example, Khanna et al. [30] investigated the reaction of multiple active sites of $\mathrm{Al}_{16}{ }^{-}, \mathrm{Al}_{17}{ }^{-}$, and $\mathrm{Al}_{18}{ }^{-}$, which resulted in the production of $\mathrm{H}_{2}$ from water, and found that the reactions of the metal clusters with small molecules often depend on cluster size. Li et al. [31] systematically examined the splitting pathway of one to two $\mathrm{H}_{2} \mathrm{O}$ molecules in $\mathrm{Al}_{16} \mathrm{M}(\mathrm{M}=\mathrm{Al}, \mathrm{Mg}$, and $\mathrm{Bi})$ clusters to demonstrate the effect of metal doping $(\mathrm{Mg}$ and $\mathrm{Bi})$ on aluminum hydrolysis in water. Reber et al. [32] examined the reactions of $\mathrm{Al}_{n}{ }^{-}+\mathrm{H}_{2} \mathrm{O}$ (where $n=7-18$ ), and showed how the complementary active sites may be best identified. Gas-phase reaction experiments on size-selected $\mathrm{Al}^{+}{ }_{n}(n=3-19)$ and $\mathrm{H}_{2} \mathrm{O}$ have been reported [33], in which the products $\mathrm{Al}_{n} \mathrm{O}^{+}$and $\mathrm{Al}_{n}\left(\mathrm{H}_{2} \mathrm{O}\right)^{+}$are detected. The production of $\mathrm{Al}_{n} \mathrm{O}^{+}$implies $\mathrm{H}_{2}$ generation. The results of both experimental and theoretical studies show that $\mathrm{H}_{2}$ can be generated using $\mathrm{Al}$ clusters comprising their cations and anions.

However, a few studies have focused on doped Al clusters. In particular, generating complete $\mathrm{H}_{2}$ using only one water molecule is rarely reported. Only Arakawa et al. [33] reported the generation of $\mathrm{H}_{2}$ with $\mathrm{Al}_{n}$ cations, but the mechanism is unclear. Therefore, we perform calculations to explore the mechanism for complete generation of the $\mathrm{H}_{2}$ from a single $\mathrm{H}_{2} \mathrm{O}$ molecule. Based on density functional theory (DFT) calculations, we have found that two $\mathrm{H}$ atoms can be extracted from one $\mathrm{H}_{2} \mathrm{O}$ molecule in a three-step reaction by the catalysis of the $\mathrm{Al}_{6} \mathrm{Cu}$ cluster. The reactant, product, and transition state (TS) are 
optimized and the reaction mechanism is analyzed.

\section{Computational methods}

First principles calculations are performed with the hybrid functional DFT (B3LYP) [34] implemented in the Gaussian 09 program [35]. B3LYP is a gradient-corrected hybrid DFT with exchange-correlation functional in Becke's three-parameter form, which includes a mixture of Hartree-Fock exchange with the VWN functional III for local correlation and LYP terms for non-local correlation. The mixed basis set of the 6-31G $(\mathrm{d}, \mathrm{p})$ is adopted. Geometry optimization and frequency calculation of all stationary points (reactants, products, and TS) for the reaction of $\mathrm{H}_{2} \mathrm{O}$ molecule and $\mathrm{Al}_{6} \mathrm{Cu}$ clusters are performed at the same theoretical level. Initially, the isomers of $\mathrm{Al}_{6} \mathrm{Cu}$ are optimized. Then, the adsorption sites are chosen and the $\mathrm{H}_{2} \mathrm{O}$ molecule is placed to construct the adsorption complex, which is the reactant of the first reaction step. One $\mathrm{H}_{2}$ molecule and a separate $\mathrm{O}$ on $\mathrm{Al}_{6} \mathrm{Cu}$ is the product of the last reaction step. After the reactant and product are optimized and their energy stability has been confirmed with harmonic frequency analysis, the TS is searched by using the QST2 method. The obtained TS is confirmed with TS optimization algorithm and another frequency calculation. All structures are fully optimized to local minima except for the TSs that are optimized with the constrained optimizations. Vibrational frequencies are used to confirm the minima geometries and the TS. Intrinsic reaction coordinate (IRC) calculations are performed at the same level to confirm the connection of the product and the reactant. Similarly, more TSs have been found, and the entire reaction path has been constructed. The activation energy ( $\left.E_{\text {activation }}\right)$ or energy barrier for each reaction step is calculated according to the following formula: 


$$
E_{\text {activation }}=E(\mathrm{TS})-E(\text { reactant })
$$

To determine the effect of the temperature on the $\mathrm{H}_{2} \mathrm{O} @ \mathrm{Al}_{6} \mathrm{Cu}$ complex and the final product $\mathrm{H}_{2} @ \mathrm{Al}_{6} \mathrm{CuO}$, we performed molecular dynamics simulations using the atom centered density matrix propagation molecular dynamics model at $300 \mathrm{~K}$, using the optimized structure as the initial structure. The time step is $0.1 \mathrm{fs}$ and the total simulation time reaches 0.5 ps (5000 time steps). All calculations are convergent to the default criterion of Gaussian 09. The standard self-consistent energy convergence in the calculation is $1.0 \times 10^{-6}$ Hartree.

\section{Results and discussion}

\section{1. $\mathrm{Al}_{6} \mathrm{Cu}$ Cluster}

The stable isomers of $\mathrm{Al}_{6} \mathrm{Cu}$ cluster are searched. The obtained structure is shown in Fig. 1(a). The figure displays that $\mathrm{Cu}$ atom is in the center of the planar hexagon formed by six $\mathrm{Al}$ atoms, which is obviously different from $\mathrm{Al}_{6} \mathrm{Si}$ [36] and $\mathrm{Al}_{6} \mathrm{C}$ [37] clusters where the obvious three-dimensional structure comprises all the atoms.

Binding energy $\left(E_{b}\right)$ is the energy necessary to dissociate a cluster into separate atoms completely; $E_{b}$ is an index of the energy stability of a cluster. Therefore, we use $E_{b}$ to evaluate the stability of the $\mathrm{Al}_{6} \mathrm{Cu}$ cluster. $E_{b}$ is calculated using:

$$
E_{b}=E\left(\mathrm{Al}_{6} \mathrm{Cu}\right)-6 E(\mathrm{Al})-E(\mathrm{Cu})
$$

where $E\left(\mathrm{Al}_{6} \mathrm{Cu}\right)$ is the total energy of the $\mathrm{Al}_{6} \mathrm{Cu} ; E(\mathrm{Al})$ and $E(\mathrm{Cu})$ are the energy of single $\mathrm{Al}$ and $\mathrm{Cu}$ atom, respectively. The absolute value of the calculated binding energy $\left(E_{b}\right)$ of $\mathrm{Al}_{6} \mathrm{Cu}$ cluster is $-13.5704 \mathrm{eV}$, which is larger than that $(-12.42 \mathrm{eV})$ of the pure cluster $\mathrm{Al}_{7}$ [37] but smaller than that of $\mathrm{Al}_{6} \mathrm{Si}$ (about -14.77 eV) [36] and $\mathrm{Al}_{6} \mathrm{C}$ (about 
$-16.32 \mathrm{eV}$ ) [37]. $\mathrm{Cu}$ atom remarkably increases the stability of the pure cluster.

Experimentally, the $\mathrm{Al}_{6} \mathrm{Cu}$ cluster could be generated by a magnetron-sputter cluster-ion source and thermalized through collisions with $\mathrm{N}_{2}$ gas cooled by liquid nitrogen. According to the reaction $\mathrm{Al}_{6} \mathrm{Cu}+\mathrm{H}_{2} \mathrm{O} \rightarrow \mathrm{O} @ \mathrm{Al}_{6} \mathrm{Cu}+\mathrm{H}_{2}$, $\mathrm{O} @ \mathrm{Al}_{6} \mathrm{Cu}$ and $/$ or $\mathrm{H}_{2} \mathrm{O} @ \mathrm{Al}_{6} \mathrm{Cu}$ could be observed as major reaction products to estimate the generation ratio of $\mathrm{H}_{2}$; the details can be found elsewhere [33].

\subsection{Adsorption of a $\mathrm{H}_{2} \mathrm{O}$ molecule on the isomers of $\mathrm{Al}_{6} \mathrm{Cu}$ cluster}

The adsorption of a $\mathrm{H}_{2} \mathrm{O}$ molecule on $\mathrm{Al}_{6} \mathrm{Cu}$ cluster is the first step to capture $\mathrm{H}_{2} \mathrm{O}$ molecule. The stable structure of the $\mathrm{H}_{2} \mathrm{O} @ \mathrm{Al}_{6} \mathrm{Cu}$ complex is optimized, as shown in Fig. 1(b). The energy stability has been confirmed with frequency analysis. The adsorption energy $\left(E_{a}\right)$ can be used to evaluate the adsorption strength or the capture ability of the $\mathrm{Al}_{6} \mathrm{Cu}$ cluster; $E_{a}$ is defined as

$$
E_{a}=E\left(\mathrm{H}_{2} \mathrm{O} @ \mathrm{Al}_{6} \mathrm{Cu}\right)-E\left(\mathrm{Al}_{6} \mathrm{Cu}\right)-E\left(\mathrm{H}_{2} \mathrm{O}\right)
$$

where $E\left(\mathrm{H}_{2} \mathrm{O} @ \mathrm{Al}_{6} \mathrm{Cu}\right)$ is the energy of the adsorption system, $E\left(\mathrm{Al}_{6} \mathrm{Cu}\right)$ is the energy of the $\mathrm{Al}_{6} \mathrm{Cu}$ cluster, and $E\left(\mathrm{H}_{2} \mathrm{O}\right)$ is the energy of a free $\mathrm{H}_{2} \mathrm{O}$ molecule. The present adsorption energy for $\mathrm{H}_{2} \mathrm{O}$ molecule on $\mathrm{Al}_{6} \mathrm{Cu}$ cluster is $-0.4605 \mathrm{eV}$, which is smaller than that $(-0.7098 \mathrm{eV})$ on $\mathrm{Al}_{17}$ cluster calculated by $\mathrm{Li}$ et al [31], implying that the reactant could not be significantly changed at room temperature. The calculated adsorption energy of $\mathrm{H}_{2} \mathrm{O} @ \mathrm{Al}_{7}^{-}$is only $-0.3429 \mathrm{eV}$. Thus, the adsorption energy of $\mathrm{Al}_{6} \mathrm{Cu}$ cluster is much stronger than that of $\mathrm{Al}_{7}^{-}$cluster; consequently, $\mathrm{Cu}$-doped aluminum cluster has obviously larger adsorption energy. To determine the effect of temperature on the complex structure of $\mathrm{Al}_{6} \mathrm{Cu}$ and $\mathrm{H}_{2} \mathrm{O}$, we performed molecular dynamics simulation at $300 \mathrm{~K}$ using the 
obtained structures as the initial structure. The result ' $b$ ' in Fig. 2 shows that the distance $\left(D_{c}\right)$ between the geometric centers of $\mathrm{Al}_{6} \mathrm{Cu}$ cluster and that of $\mathrm{H}_{2} \mathrm{O}$ molecule increases (from $4.30 \AA$ to final $6.72 \AA$ ) with time. We also perform another simulation with the initial structure of the $\mathrm{H}_{2} \mathrm{O}$ molecule far away from $\mathrm{Al}_{6} \mathrm{Cu}$. The result ' $\mathrm{a}$ ' in Fig. 2 shows that the far $\mathrm{H}_{2} \mathrm{O}$ molecule is close to the $\mathrm{Al}_{6} \mathrm{Cu}$ cluster, and the final $D_{c}$ is also approximately 6.72 $\AA$. These results imply that $\mathrm{Al}_{6} \mathrm{Cu}$ cluster can adsorb $\mathrm{H}_{2} \mathrm{O}$ molecule and provide the first reactant structure at $300 \mathrm{~K}$, although the equilibrium $D_{c}$ becomes larger.

To understand the capture ability and favorable adsorption sites for the $\mathrm{H}_{2} \mathrm{O}$ molecule, we analyzed the atomic polar tensors (APT) charge of $\mathrm{Al}_{6} \mathrm{Cu}$ cluster, and that of the $\mathrm{Al}_{7}^{-}$ cluster as the counterpart. Careful examination of the charge on each atom indicates charge transfer between $\mathrm{H}_{2} \mathrm{O}$ molecule and the clusters because the total charge on $\mathrm{H}_{2} \mathrm{O}$ molecule is non-zero. The results in Fig. 3 show that for $\mathrm{H}_{2} \mathrm{O} @ \mathrm{Al}_{7}^{-}$, all the $\mathrm{Al}$ atoms have negative charge and one of $\mathrm{H}$ atom is charged with $+0.202 \mathrm{e}$ for an $\mathrm{H}_{2} \mathrm{O}$ molecule that is close to the $\mathrm{Al}$ atom with $-0.110 \mathrm{e}$ of charge. For the $\mathrm{Al}_{6} \mathrm{Cu}$ cluster, $\mathrm{a}+0.111 \mathrm{e}$ charge is detected on one of the $\mathrm{Al}$ atoms because of the doped $\mathrm{Cu}$ atom, which adsorbs the $\mathrm{O}$ atom charged with 0.535e in the $\mathrm{H}_{2} \mathrm{O}$ molecule. Therefore, the adsorption energy between $\mathrm{H}_{2} \mathrm{O}$ molecule and $\mathrm{Al}_{6} \mathrm{Cu}$ cluster is obviously stronger than that between $\mathrm{H}_{2} \mathrm{O}$ molecule and $\mathrm{Al}_{7}^{-}$. It also means that the coulomb interaction is responsible for the adsorption energy and the doped $\mathrm{Cu}$ atom significantly increases the ability of the cluster to capture $\mathrm{H}_{2} \mathrm{O}$ molecule.

\section{3. $\mathrm{H}+\mathrm{OH}$ product on the $\mathrm{Al}_{6} \mathrm{Cu}$ cluster}

The whole reaction path for $\mathrm{H}_{2}$ generation on the $\mathrm{Al}_{6} \mathrm{Cu}$ cluster is presented in Fig. 4 . First, the product $\mathrm{H}+\mathrm{OH}$ is considered as in the previous investigations $[30,31]$. The 
energy stable geometry of $\mathrm{H}+\mathrm{OH}$ ("B" in Fig. 4) on the $\mathrm{Al}_{6} \mathrm{Cu}$ cluster has been obtained (Fig. 4), and confirmed by frequency analysis. We also have obtained the TS using the QST2 algorithm. Then, both optimizations with TS algorithm and frequency calculation are carried out to confirm the TS (TS1 in Fig. 4). The barrier is $0.5517 \mathrm{eV}$ and the imaginary frequency of TS1 reaches $-1201.0 \mathrm{~cm}^{-1}$. Starting from TS1, we optimize the reaction path with IRC algorithm.

\section{4. $\mathrm{H}_{2}+\mathrm{O}$ product on the $\mathrm{Al}_{6} \mathrm{Cu}$ cluster}

Interestingly, another product $\mathrm{O}+\mathrm{H}_{2}$ (" $\mathrm{D}$ " in Fig. 4) on the $\mathrm{Al}_{6} \mathrm{Cu}$ has been found. Its energy is $2.4821 \mathrm{eV}$ higher than that of the structure "B". However, the released energy of the first reaction reaches $2.4740 \mathrm{eV}$, which is slightly less than the energy barrier between " $\mathrm{B}$ " and TS3. The adsorption of the final product $\mathrm{H}_{2} @ \mathrm{Al}_{6} \mathrm{CuO}$ is $0.1464 \mathrm{eV}$. Molecular dynamics simulation at $300 \mathrm{~K}$ is performed using the structure of the final product from the reaction path to determine the temperature effect on the product. The result in Fig. 5 demonstrates that the distance $\left(D_{c}\right)$ between geometric center of $\mathrm{H}_{2}$ and $\mathrm{Al}_{6} \mathrm{CuO}$ cluster increases with the duration of simulation, implying that $\mathrm{H}_{2}$ can be directly be released. To explore the relationship between the structure " $\mathrm{D}$ " and the reactant structure " $\mathrm{B}$ ", we searched the TS with the new reactant and product. A new TS (i.e., TS3 in Fig. 4), with different geometry and energy from those of TS1, is obtained. We performed IRC calculations after confirming the TS (i.e., TS3) by frequency analysis. Furthermore, another $\mathrm{H}+\mathrm{OH}$ geometry ("C"C in Fig. 4) on the $\mathrm{Al}_{6} \mathrm{Cu}$ is found, with energy that is $0.3958 \mathrm{eV}$ higher than that of B. Further calculations show that the structures " $B$ " and " $C$ " are connected by a lower TS (i.e., TS2 in Fig. 4). The barrier is only $0.6697 \mathrm{eV}$, implicating 
that the transition from the end of extracting one $\mathrm{H}$ atom to the start of extracting the second $\mathrm{H}$ atom is practicable. The barrier of TS3 is $2.8585 \mathrm{eV}$, which means that the extraction of the second $\mathrm{H}$ atom needs more energy than that of the first one. However, the energy of TS3 in Table 1 is $0.7803 \mathrm{eV}$ higher than that of TS1. Considering the conservation of the system, the total energy to trigger the whole reaction is the first barrier plus the additional energy of the last barrier above the first barrier. By using Table 1, the calculated total energy is $1.3321 \mathrm{eV}$. We also noted that the last reaction releases energy of $0.7722 \mathrm{eV}$ after overcoming the TS. The energy breaks the $\mathrm{H}_{2}+\mathrm{O} @ \mathrm{Al}_{6} \mathrm{Cu}$ complex into $\mathrm{H}_{2}$ and $\mathrm{O} @ \mathrm{Al}_{6} \mathrm{Cu}$ cluster, which means that the triggering energy of $1.3321 \mathrm{eV}$ can extract a free $\mathrm{H}_{2}$ from a $\mathrm{H}_{2} \mathrm{O}$ molecule. Thus, the $\mathrm{Al}_{6} \mathrm{Cu}$ cluster plays a remarkable role in the catalysis of the reaction for $\mathrm{H}_{2}$ generation from water molecule.

We calculated the APT charges for "B" and "C" structures (Fig. 6). An interesting charge distribution is the negative charge of the separate $\mathrm{H}$ atom, which results in a $+0.497 \mathrm{e}$ charge on the $\mathrm{Al}$ atom (labeled with 2 in the figure). The positive charged $\mathrm{Al}$ atom (labeled with 1) then adsorbs the negative $\mathrm{O}$ atom of $\mathrm{OH}$ radical. As a result, the $\mathrm{OH}$ radical approaches a $\mathrm{Al}$ (labeled with 1 in the figure) and form a new structure " $\mathrm{C}$ " with more positive charge on the $\mathrm{Al}$ atom (increase from +0.097 to $+0.552 \mathrm{e}$ ). Therefore, the change of the charge on atoms alters of the electrostatic interactions between $\mathrm{Al}$ atom and $\mathrm{OH}$ radical, which further induces the movement of $\mathrm{OH}$. Finally, a new structure " $\mathrm{C}$ " formed as a reactant for the next reaction, which extracts the second $\mathrm{H}$ atom to form the $\mathrm{H}_{2}$ molecule.

\section{Conclusions}


In conclusion, we identified the reaction paths for generation of an $\mathrm{H}_{2}$ molecule from one $\mathrm{H}_{2} \mathrm{O}$ molecule via catalysis with a small $\mathrm{Al}_{6} \mathrm{Cu}$ cluster. The extraction of $\mathrm{H}_{2}$ is completed with two reactions. The energy barrier of the first one is $0.5517 \mathrm{eV}$ and that of the second one is $2.858 \mathrm{eV}$. The product of the first reaction can transit to the reactant of the second reaction by overcoming a $0.6697 \mathrm{eV}$ barrier. The $\mathrm{H}_{2}$ molecule is obtained with a three-step reaction. Considering the conservation of the system, the total energy to trigger the whole reaction and to release a free $\mathrm{H}_{2}$ molecule is $1.3321 \mathrm{eV}$. The reactions show close relationship with the charge distribution of the $\mathrm{Al}_{6} \mathrm{Cu}$ cluster. The dopant $\mathrm{Cu}$ atom is responsible for the increase of the ability of the $\mathrm{Al}_{6} \mathrm{Cu}$ cluster to capture $\mathrm{H}_{2} \mathrm{O}$ before reaction and the suitable charge distribution to support the two reactions. Molecular dynamics simulation for both the reactant and product shows that $300 \mathrm{~K}$ is a favorable temperature for the reaction, because the $\mathrm{H}_{2} \mathrm{O}$ molecule can be caught and the $\mathrm{H}_{2}$ molecule can be directly released at $300 \mathrm{~K}$. The present findings provide a new insight into the release of $\mathrm{H}_{2}$ from $\mathrm{H}_{2} \mathrm{O}$ molecule via catalysis with $\mathrm{Al}_{6} \mathrm{Cu}$ cluster, which is a promising way to produce hydrogen.

\section{Acknowledgment}

This work was supported by the National Science Foundation of China (NSFC) under Grant Nos. NSFC-11574125 and NSFC-11374132, as well as the Taishan Scholars project of Shandong Province (ts201511055).

\section{References}

[1] Orhan MF, Babu BS. Investigation of an integrated hydrogen production system based 
on nuclear and renewable energy sources: Comparative evaluation of hydrogen production options with a regenerative fuel cell system. Energy 2015;88:801-820.

[2] Ruban P, Sellappa K. Development and performance of bench-scale reactor for the photocatalytic generation of hydrogen. Energy 2014;73:926-932.

[3] Zou MS, Huang HT, Sun Q, et al. Effect of the storage environment on hydrogen production via hydrolysis reaction from activated Mg-based materials. Energy 2014;76:673-678.

[4] Hoffmann P. Tomorrow's energy: hydrogen, fuel cells, and the prospects for a cleaner planet. MIT Press; 2012.

[5] Navarro RM, Pena MA, Fierro JLG. Hydrogen production reactions from carbon feedstocks: fossil fuels and biomass. Chem Rev 2007;107(10):3952-3991.

[6] Pen MA, Gomez JP, Fierro JLG. New catalytic routes for syngas and hydrogen production. Appl Catal A 1996;144(1):7-57.

[7] Armor JN. The multiple roles for catalysis in the production of $\mathrm{H}_{2}$. Appl Catal A 1999;176(2):159-176.

[8] Trimm DL, Önsan ZI. Onboard fuel conversion for hydrogen-fuel-cell-driven vehicles. Rev Sci Eng 2001;43(1-2):31-84.

[9] Bockris JOM. The origin of ideas on a hydrogen economy and its solution to the decay of the environment. Int J Hydrogen Energy 2002;27(7):731-740.

[10] Sun Y, Tian Y, Li S. Theoretical study on reaction mechanism of aluminum-water system. Chin J Chem Phys 2008;21(3):245-249.

[11] Martínez SS, Benítes WL, Gallegos AAÁ. Recycling of aluminum to produce green 
energy. Sol Energ Mat Sol Cells 2005;88(2):237-243.

[12] Cho CY, Wang KH, Uan JY. Evaluation of a new hydrogen generating system: Ni-rich magnesium alloy catalyzed by platinum wire in sodium chloride solution. Mater Trans 2005;46(12):2704-2708.

[13] Russo MF, Li R, Mench M. Molecular dynamic simulation of aluminum-water reactions using the ReaxFF reactive force field. Int $\mathrm{J}$ Hydrogen Energy 2011;36(10):5828-5835.

[14] Xing Z, Hua W. Hydrogen production by two-step water-splitting thermochemical cycle based on metal oxide redox system. Prog Chem 2010;22(5):1010-1020.

[15] Gai WZ, Fang CS, Deng ZY. Hydrogen generation by the reaction of Al with water using oxides as catalysts. Int J Energy Research 2014;38(7):918-925.

[16] Wang CC, Chou YC, Yen CY. Hydrogen generation from Aluminum and aluminum alloys powder. Proc Engng. 2012;36:105-113.

[17] Uehara K, Takeshita H, Kotaka H. Hydrogen gas generation in the wet cutting of aluminum and its alloys. J Mater Process Technol 2002;127(2):174-177.

[18] Munoz AG, Bessone JB. Pitting of aluminium in non-aqueous chloride media. Corros Sci 1999;41(7):1447-1463.

[19] Dolega Ł, Adamczyk-Cieślak B, Mizera J. Corrosion resistance of model ultrafine-grained Al-Li alloys produced by severe plastic deformation. J Mater Sci 2012;47(7):3026-3033.

[20] Skrovan J. Activation Energy for the Corrosion of Aluminum Powders in Water. ECS Trans 2012;41(25):143-154. 
[21] Tomasz Edith TC. International Patent Application PCT/CA2006/001300. February 15, 2007.

[22] Li R. Molecular dynamic simulation of aluminum/water reaction using reactive force field. The Pennsylvania State University; 2010.

[23] Fan MQ, Xu F, Sun LX. Hydrolysis of ball milling Al-Bi-hydride and Al-Bi-salt mixture for hydrogen generation. J Alloys Compd 2008;460(1):125-129.

[24] Fan MQ, Xu F, Sun LX. Studies on hydrogen generation characteristics of hydrolysis of the ball milling Al-based materials in pure water. Int $\mathbf{J}$ Hydrogen Energy 2007;32(14): 2809-2815.

[25] Zidan R, Teprovich JA, Motyka T. Two step novel hydrogen system using additives to enhance hydrogen release from the hydrolysis of alane and activated aluminum. US Patent Application 2013;14/095:033.

[26] Zhao ZW, Chen XY, Hao MM. Hydrogen generation by splitting water with Al-Ca alloy. Energy 2011;36:2782-2787.

[27] Chai YJ, Dong YM, Meng HX, et al. Hydrogen generation by aluminum corrosion in cobalt(II) chloride and nickel (II) chloride aqueous solution. Energy 2014;68:204-209.

[28] Liu YG, Wang XH, Liu HZ, et al. Improved hydrogen generation from the hydrolysis of aluminum ball milled with hydride. Energy 2014;72:421-426.

[29] Álvarez-Barcia S, Flores JR. The interaction of Al atoms with water molecules: A theoretical study. J Chem Phys 2009;131(17):174307.

[30] Roach PJ, Woodward WH, Castleman AW. Complementary active sites cause size-selective reactivity of aluminum cluster anions with water. Science 
2009;323(5913):492-495.

[31] Li F, Sun L, Zhao J. Mechanisms of $\mathrm{H}_{2}$ generation for metal doped $\mathrm{Al}_{16} \mathrm{M}(\mathrm{M}=\mathrm{Mg}$ and Bi) clusters in water. Int J Hydrogen Energy 2013;38(17):6930-6937.

[32] Reber AC, Khanna SN, Roach PJ, Woodward WH, Castleman AW Jr. Reactivity of aluminum cluster anions with water: origins of reactivity and mechanisms for $\mathrm{H}_{2}$ release. J Phys Chem A 2010;114(20):6071-6081.

[33] Arakawa M, Kohara K, Ito T, Terasaki A. Size-dependent reactivity of aluminum cluster cations toward water molecules. Eur. Phys. J. D 2013; 67(4): 1-6.

[34] Raghavachari K. Perspective on "density functional thermochemistry. III. The role of exact exchange". Theor Chem Acc 2000;103(3-4):361-363.

[35] Frisch MJ, Trucks GW, Schlegel HB, Scuseria GE, Robb MA, Cheeseman JR. Gaussian 09, Revision D.01. Wallingford CT: Gaussian, Inc. 2013.

[36] Li KN, Yang CL, Wang MS. Theoretical investigations of adsorption and dissociation of $\mathrm{H}_{2}$ on cluster $\mathrm{Al}_{6} \mathrm{Si}$. Int $\mathrm{J}$ Hydrogen Energy 2015;40(29):8911-8916.

[37] Yang H, Zhang Y, Chen H. Dissociation of $\mathrm{H}_{2}$ on carbon doped aluminum cluster $\mathrm{Al}_{6} \mathrm{C}$. J Chem Phys 2014;141(6):064302. 


\section{Figure captions}

Fig. 1. Stable structures of $\mathrm{Al}_{6} \mathrm{Cu}$ and a $\mathrm{H}_{2} \mathrm{O}$ molecule adsorbed on $\mathrm{Al}_{6} \mathrm{Cu}$ cluster.

Fig. 2. Distance $D_{c}$ (in $\AA$ ) between the geometric center of $\mathrm{Al}_{6} \mathrm{Cu}$ cluster and $\mathrm{H}_{2} \mathrm{O}$ molecule vs. the simulation step.

Fig. 3. Atomic polar tensor charges of $\mathrm{H}_{2} \mathrm{O}$ adsorbed on $\mathrm{Al}_{6} \mathrm{Cu}$ and $\mathrm{Al}_{7}^{-}$cluster.

Fig. 4. The reaction path for $\mathrm{H}_{2}$ generation catalyzed by $\mathrm{Al}_{6} \mathrm{Cu}$ cluster.

Fig. 5. Distance $D_{c}$ (in $\AA$ ) between the geometric center of $\mathrm{Al}_{6} \mathrm{CuO}$ cluster and $\mathrm{H}_{2}$ molecule vs. the simulation step.

Fig. 6. Atomic polar tensor charges for "B" and "C" structures.

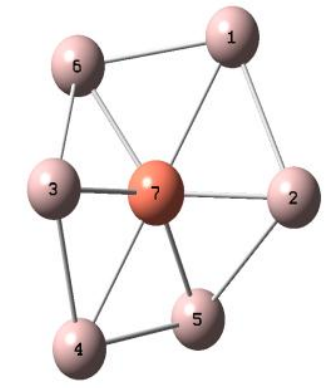

(a)

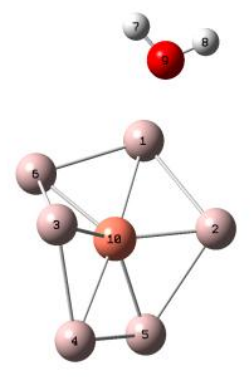

(b)

$$
\begin{gathered}
E_{b}=-13.5704 \mathrm{eV} \quad E_{a}=-0.4605 \mathrm{eV} \\
\bigodot_{\mathrm{Cu}} \bigodot_{\mathrm{Al}} \bigcirc_{\mathrm{O}} \supset_{\mathrm{H}}
\end{gathered}
$$

Fig. 1. Stable structures of $\mathrm{Al}_{6} \mathrm{Cu}$ and $\mathrm{H}_{2} \mathrm{O}$ molecule adsorbed on $\mathrm{Al}_{6} \mathrm{Cu}$ cluster. 


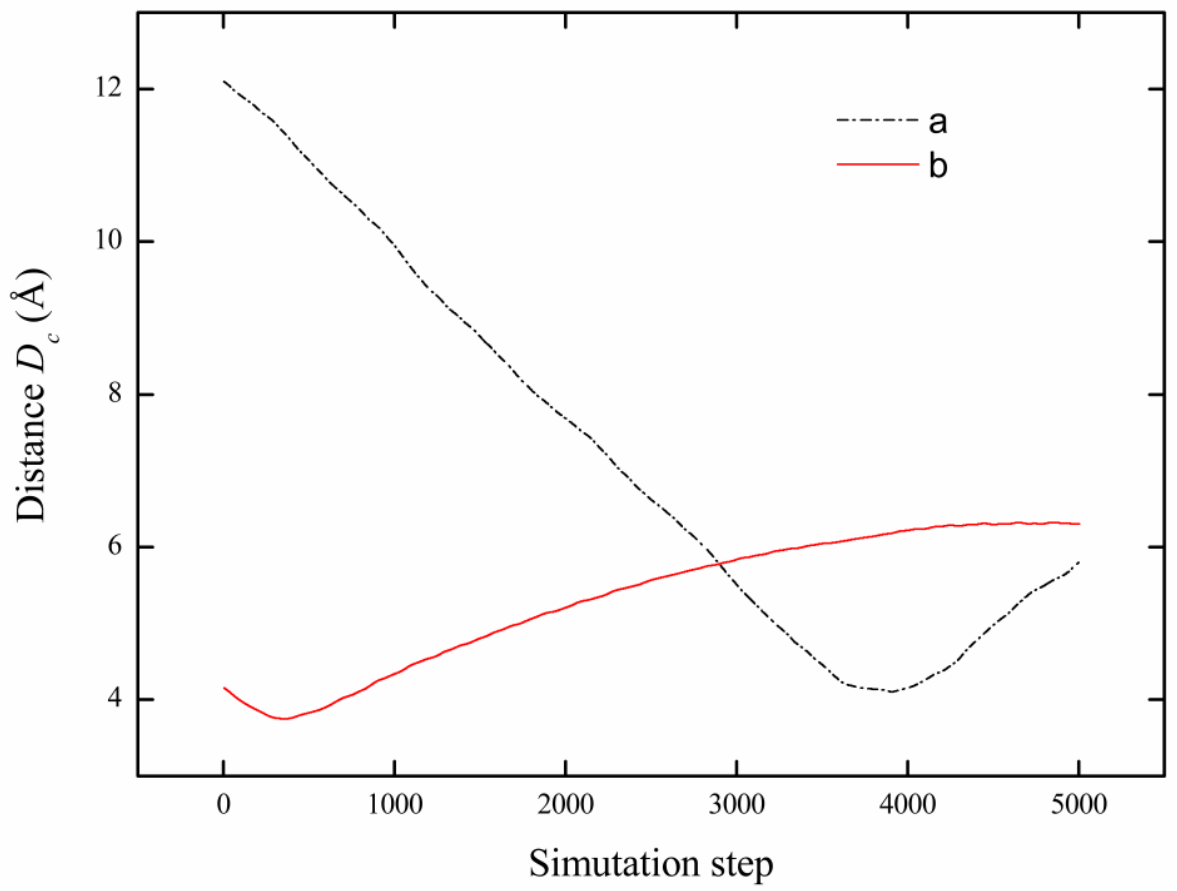

Fig. 2. Distance $D_{c}$ (in $\AA$ ) between the geometric center of $\mathrm{Al}_{6} \mathrm{Cu}$ cluster and $\mathrm{H}_{2} \mathrm{O}$ molecule vs. the simulation step. 

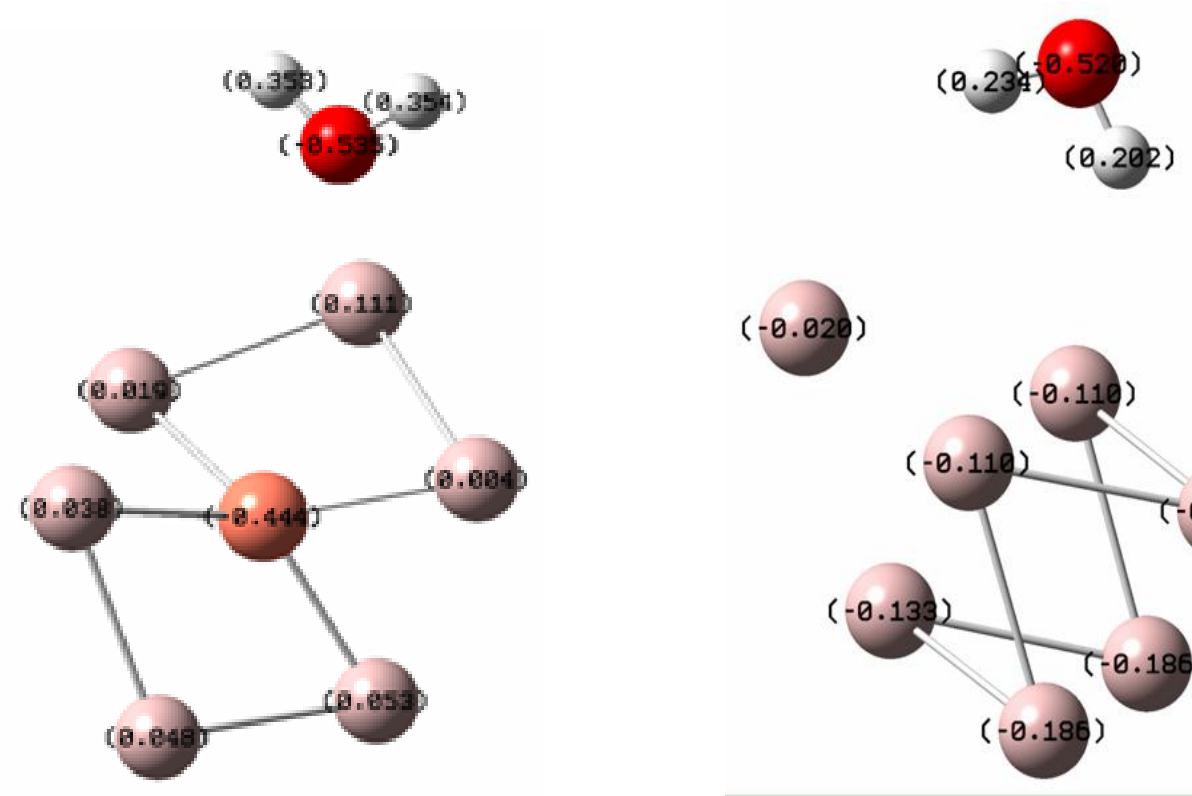

$\bigcirc_{\mathrm{Cu}} \bigcirc_{\mathrm{Al}} \bigcirc_{\mathrm{O}} \boldsymbol{\nu}_{\mathrm{H}}$

Fig. 3. Atomic polar tensor charges of $\mathrm{H}_{2} \mathrm{O}$ adsorbed on $\mathrm{Al}_{6} \mathrm{Cu}$ and $\mathrm{Al}_{7}{ }^{-}$cluster. 


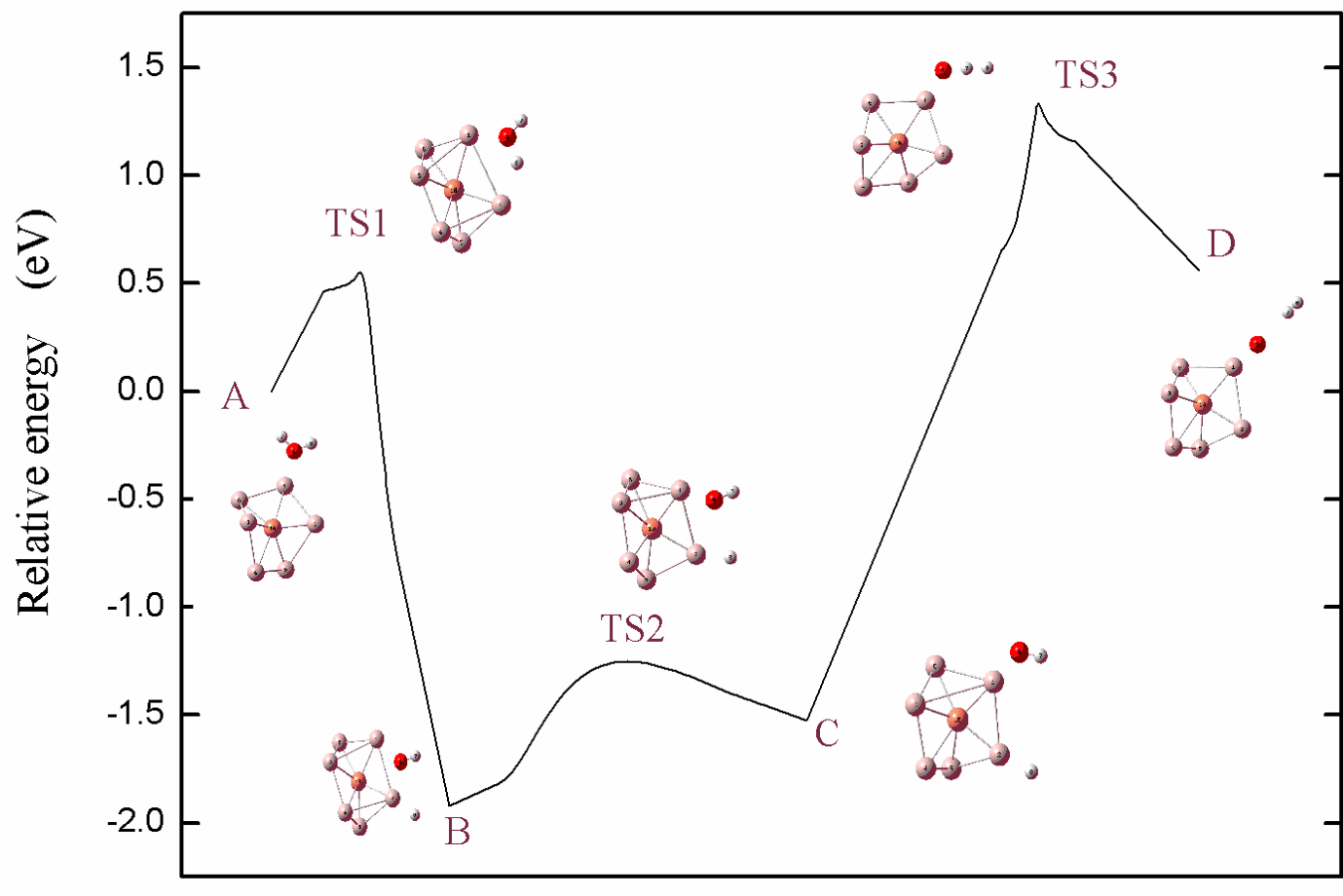

Reaction coordinate

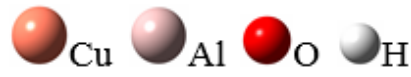

Fig. 4. The reaction path for $\mathrm{H}_{2}$ generation catalyzed by the $\mathrm{Al}_{6} \mathrm{Cu}$ cluster. 


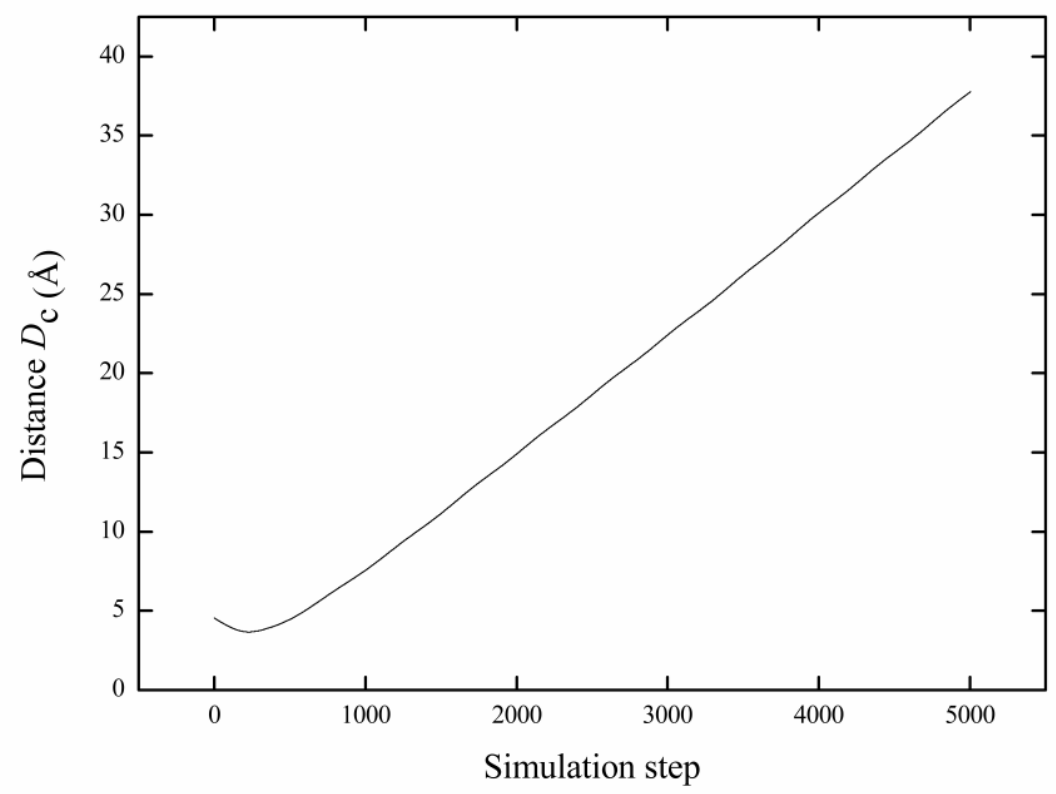

Fig. 5. Distance $D_{c}$ (in $\AA$ ) between the geometric center of $\mathrm{Al}_{6} \mathrm{CuO}$ cluster and $\mathrm{H}_{2}$ molecule vs. the simulation step. 


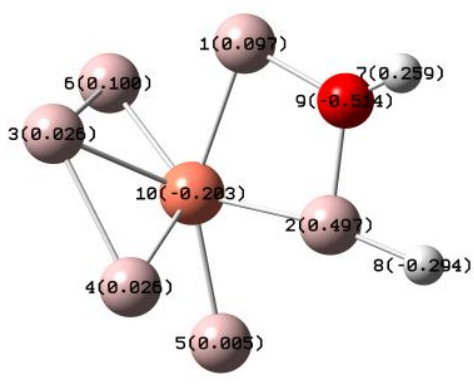

B

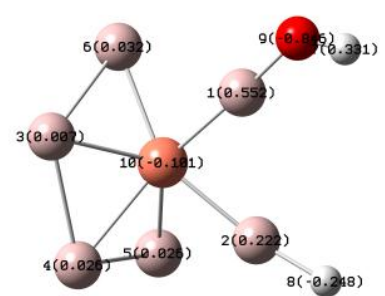

C

\section{$\vartheta_{\mathrm{Cu}} \bigcirc_{\mathrm{Al}} \bigcirc_{\mathrm{O}} \partial_{\mathrm{H}}$}

Fig. 6. Atomic polar tensor charges for " $\mathrm{B}$ " and "C" structures. 
Table 1. Bond length and energy for the relative structures

\begin{tabular}{ccccc}
\hline Cluster & H-O $(\AA)$ & H-O $(\AA)$ & H-H $(\AA)$ & Energy $(\mathbf{e V})$ \\
\hline $\mathbf{A}$ & 0.96949 & 0.96973 & 1.57197 & 0 \\
TS1 & 1.19060 & 0.97356 & 1.80529 & 0.5518 \\
$\mathbf{B}$ & 2.71882 & 0.96672 & 2.88688 & -1.9222 \\
$\mathbf{T S 2}$ & 3.20628 & 0.96233 & 3.26875 & -1.2525 \\
$\mathbf{C}$ & 4.73258 & 0.96155 & 4.61329 & -1.5264 \\
TS3 & 2.14931 & 1.14209 & 1.00815 & 1.3321 \\
$\mathbf{D}$ & 3.11878 & 2.37137 & 0.74746 & 0.5599 \\
\hline
\end{tabular}

